\title{
1 Intra-annual tracheid production in balsam fir stems and the effect of
}

\section{2 meteorological variables}

3

4 Annie Deslauriers ${ }^{1-2}$, Hubert Morin ${ }^{1}$

5

$6 \quad{ }^{1}$ Département des sciences fondamentales

7 Université du Québec à Chicoutimi

8555 , boulevard de l'Université

9 Chicoutimi (Québec) Canada

10 G7H 2B1

11

$12{ }^{2}$ Current address

13 Dipartimento Territorio e sistemi Agro-Forestali

14 Università degli Studi di Padova

15 Agripolis

16 Viale dell'Università 16

1735020 Legnaro (PD)

18 ITALY

19

20 e-mail of the author: annie.deslauriers@ unipd.it

21 Tel: $39049827-2752$

22 Fax: $39049827-2686$ 


\section{Abstract}

2 Tracheid production of balsam fir in the Québec boreal forest (Canada) was studied by

3 repeated cell analysis to investigate the influence of meteorological variables during the

4 growing seasons 1998 to 2000 . Wood micro-cores were extracted on a weekly basis

5 throughout the growing season and sections were prepared in order to count the total

6 number of cells produced. From the weekly cell number obtained, the rate of tracheid

7 production was calculated and correlated with meteorological variables. The average

8 total number of cells produced per year was reasonably uniform, increasing only from

936.6 in 1998 , to 41.1 in 2000 . However, different cell production rates were noted

10 during the growing season. Regression analysis revealed that the cell production rate

11 was largely dependent on minimum air and soil temperature during most of the cell

12 production period. Mean and maximum temperature had less influence on cell

13 production. Moreover, the influence of temperature was higher during earlywood

14 production mainly from the end of May to mid-July. Lagging the weather data by 1 to 5

15 days decreased the relationship between temperature and cell production, showing the

16 high correspondence with the same interval where cell production was measured. These

17 results suggest a fast response of the cambium to temperature variation during tree-ring

18 formation.

21 Keywords: Tracheid production, temperature, boreal forest, growing season, Abies 22 balsamea, 


\section{Introduction}

2 The boreal forest is characterized by a short growing season due to low air and soil

3 temperatures during the spring and summer months. Seasonal temperature dynamics,

4 which vary greatly from year to year, influence the start of the growing period and the

5 timing of the trees' optimal growth conditions (Creber and Chaloner 1990; Zabuga and

6 Zabuga 1990; Kirdyanov et al. 2003). Previous results have shown that balsam fir

7 (Abies balsamea (L.) Mill.) growing in the boreal forest appears to be well adapted to

8 these changing conditions and shows flexibility in the rate and duration of tree-ring

9 development (Deslauriers et al. 2003a). When tracheid production in the tree-rings of

10 balsam fir was compared over the period 1998 to 2000, it was found that an almost

11 equal amount of cells (from 36.6 to 41. 1) were achieved with a faster growth rate over

12 a shorter period or with a slower growth rate over a longer period. These results suggest

13 that the rate of tracheid production varies with the dynamics of seasonal temperature

14 variation or other weather parameters, such as precipitation and radiation.

16 Cell number and size are the two variables that define tree-ring width (Vaganov 1996).

17 Cell number, however, compared with cell size (Richardson and Dinwoodie 1960;

18 Denne 1971; Wodzicki 1971; Antonova and Stasova 1993, 1997; Horacek et al. 1999;

19 Deslauriers 2003) has less frequently been used when analysing the relationship with

20 climate (Denne 1971; Ford et al. 1978; Antonova and Stasova 1993, 1997; Wang et al.

21 2002). Since ring width and cell number are highly correlated tree-ring parameters

22 (Vaganov 1996; Camarero et al. 1998), it could be expected that climate affects both

23 parameters equally. In the boreal forest, many studies have indicated the strong

24 influence of temperature on tree-ring width, especially during June and July, (d'Arrigo

25 et al. 1992; Hofgaard et al. 1999; Wang et al. 2002; Kirdyanov et al. 2003; Mäkinen et 
1 al. 2003). Although synchronous variations between cell number and ring width were

2 observed, Wang et al. (2002) found a low correlation between ring cell number and

3 summer temperature (May-September) for black spruce located in northern Québec.

4 However, positive correlations were found between annual tracheid production and

5 pentad temperatures at the end of July. These results suggest that temperature might not

6 affect tracheid production throughout the growing season. Antonova and Stasova (1993,

7 1997) found a positive temperature influence on the cambial activity (i.e. tracheid

8 production) of Scots pine and Siberian larch growing in central Siberia, but only at the

9 start of the growing season (May-June). More recently, Kirdyanov et al. (2003) found

10 that cell size and tree-ring width of different species of larch depend on temperature

11 during the first part of the season, from June 7 to July 11 in the Siberian Subartic. Other

12 environmental factors were also found to influence tracheid production. Ford et al.

13 (1978) correlated daily solar radiation and the number of cells produced by Sitka spruce

14 over a 15-day period during the growing season. In a controlled experiment Denne

15 (1974) observed an increase in cell production at higher light intensity.

17 The aim of this study was to understand how temperature and other meteorological

18 factors control intra-annual tracheid production and the growing season of balsam fir in

19 boreal forests. In order to gain a better understanding of the relationship between radial

20 growth and weather variation, detailed analysis of tree-ring development was used. The

21 most important period during the growing season when parameters affect cell 22 production was also determined. 


\section{Methodology}

2 This study was conducted in a permanent plot of balsam fir, Lib-23 (49 $46^{\prime} 03^{\prime \prime} \mathrm{N}$;

3 72³4'19" W), situated around 150 km north of Lac-Saint-Jean, Québec (Morin, 1994).

4 The plot is located near the limit of the ecological region, which makes it interesting for

5 climate response studies. Lib-23 has a unimodal age structure with a tree establishment

6 period ranging from 1815 to 1850 and was only slightly affected by the 1974-1988

7 spruce budworm outbreak (Morin, 1994). The study site has a continental climate with

8 cold winters and warm summers. The mean temperature ranges from $-22{ }^{\circ} \mathrm{C}$ in January

9 to $24{ }^{\circ} \mathrm{C}$ in July. Mean annual temperature is $-0.7^{\circ} \mathrm{C}$ and mean annual precipitation is

$10422 \mathrm{~cm}$, with $357 \mathrm{~cm}$ falling as snow (Environment Canada 1992).

12 A $10 \mathrm{~m}$ high meteorological station was installed in a small forest clearing to monitor

13 weather conditions. The measured variables were air temperature (Tmean, Tmax and

$\left.14 \operatorname{Tmin}\left[{ }^{\circ} \mathrm{C}\right]\right)$ and relative humidity $(\mathrm{RH}, \%)$ at a height of $3 \mathrm{~m}$ above the ground. Humus

15 temperature $\left(\mathrm{Thu},{ }^{\circ} \mathrm{C}\right)$, total rainfall $(\mathrm{P}, \mathrm{mm})$, humus water content $(\mathrm{SW}, \%)$, and global

16 radiation $\left(\mathrm{Rad}, \mathrm{watt} / \mathrm{m}^{2}\right)$ were also recorded. SW and Thu were measured at a depth of

$1710 \mathrm{~cm}$, corresponding to half the thickness of the humus layer. Measurements were

18 taken every 5 minutes and stored as hourly averages in a datalogger (CR10X, Cambell

19 Scientific Corporation). From the hourly measurements, daily Tmin and Tmax were

20 found and daily averages were computed for Tmean, RH, Thu and SW. Precipitations

21 were computed as the daily sum and global radiation was transformed into daily sum

22 and expressed in $\mathrm{Mj} \mathrm{m}^{-2} \mathrm{~d}^{-1}$.

24 Tree-ring formation was analysed on ten adult trees (mean height, $17.5 \mathrm{~m}$; mean diameter at DBH, $23.7 \mathrm{~cm}$ ) in 1998, 1999 and 2000, as described in Deslauriers et al. 
1 (2003a). In 1998, 20 trees were sampled before the start of the growing season and 10

2 trees with a similar average number of cells per ring were selected in order to ensure

3 comparable growth rates. Surgical bone sampling needles (model: DBMNI-1501) were

4 used for the weekly extraction of small cores of wood and bark, collected in a spiral

5 fashion up the stems at a height of around $1.3 \mathrm{~m}$, from May to October. The cores were

$61 \mathrm{~mm}$ in diameter and 15-20 mm long, containing 4 to 6 rings. Every week, one wood

7 core per tree was taken at least $10 \mathrm{~cm}$ from the previous one to avoid the presence of

8 resin ducts in the next core, as this is a common disturbance reaction with balsam fir.

9 Microcores presenting ring development malformation, mainly caused by late frosts,

10 were not analysed.

12 Wood cores were fixed in paraffin and sections (10-12 $\mu \mathrm{m}$ thickness) were prepared

13 with a microtome. The sections were stained with cresyl fast violet $(0.05 \%$ in water $)$

14 and observed under normal and polarised light to differentiate the developing xylem

15 cells. For each sample, the number of total cells $n_{t}$ was counted along three radial files

16 and the total number averaged. The number $n_{t}$ included cells in the phases of radial

17 enlargement, cell wall thickening, and the number of mature cells (Deslauriers et al.

18 2003a). The number of cells in the annual rings varies within the tree circumference and

19 consequently among different samples. The number of cells was therefore counted on

20 three radial files of the three rings formed before the developing ring and used for a cell

21 number circumference correction of the developing ring (Rossi et al. 2003).

23 For each tree, the cell production rate (cell/day) was found for each tree by the weekly

24 difference of the total cell $n_{t}$ divided by 7 (equation 1 ) and average for each year.

25 [1] Cell/day $=\left(n_{t^{-}} n_{t-1}\right) / 7$ 
1 In latewood however, negative cell fluctuations were produced when the weekly $n_{t}$ was

2 lower than that of the preceding week (figure 1). These were observed when only a

3 small number of new cells were developing over a period of several weeks at the end of

4 the growing season. To avoid estimation problems at the end of cell production, the

5 period analysed each year corresponds to the period when the majority of the cells were

6 produced during the growing season, as calculated by the Gompertz equation, removing

7 approximately the last 3-4 latewood cells formed (equation 2 and figure 1).

8 The Gompertz function is defined as:

$9 \quad[2] \quad y=a \exp \left(-\mathrm{e}^{(\beta-\kappa \mathrm{t})}\right)$

10 The time required for the major period of cell formation $\mathbf{d}$ to occur is defined as:

$11[3] \quad d=4 / \kappa$

12 Where $\boldsymbol{y}$ is the weekly cumulative number of cells, $\mathbf{t}$ is time computed in days since the

13 first sampling date where $\mathrm{t}=0, \boldsymbol{a}$ is the upper asymptote of the maximum number of cells

14 where at $t_{\mathrm{i}} y \cong a, \beta$ is the $x$-axis placement parameter, and $\kappa$ is the rate of change

15 parameter (Cheng and Gordon 2000).

17 The relationships between cell production rate and meteorological variables were found

18 with correlations and simple regression analysis. To assess the presence of a time-lag

19 effect, cross-correlation analysis were performed. The daily weather data were averaged

20 for different 7-day periods: (1) the exact 7-day period between each sample day

21 (referred to as lag 0) and (2) the 7-day period was shifted backwards from 1 to 5 days

22 before the sampling date (referred to as lag 1 to lag 5). All weather variables were

23 averaged as described above and, in addition, weekly Tmin and Tmax were computed to

24 represent the lowest and highest temperature of the average 7-day period. Simple

25 correlations (Pearson, $p<0.05$ ) were computed (SAS Institute Inc. 1990) between cell 
1 production rate and weather data. Linear regressions were performed (SAS Institute Inc.

2 1990) for the temperature related variables. A square root (sqrt) transformation was 3 applied on the cell production rate to meet the assumptions of homogeneity of variances

4 (homoscedasticity) when performing the correlation and regression analysis (Zar 1999). 5 


\section{Results}

2 Air temperature increased from April to May and decreased only at the end of August

3 (figure 2). The minimum temperature was generally above $0{ }^{\circ} \mathrm{C}$ after the beginning of

4 May in 1998 and 1999, or after mid-May in 2000. The increase in humus temperature

5 generally lagged behind the increase in minimum air temperature, but only at the

6 beginning of May when snow is still melting. Over the three years, the main

7 temperature differences were observed in May, with warm temperatures in 1999 and

8 cold ones in 2000 . By June, the mean temperature had generally reached $15{ }^{\circ} \mathrm{C}$ (figure

9 2). Precipitations were well distributed and dry periods rarely exceeded one week. The

10 daily cell production rate, estimated from a weekly sampling, was higher in June, or in

11 July, when the transition from earlywood to latewood was observed later in the growing

12 season (figure 2). Cell production in May 1999 started much earlier than the other years,

13 but a low cell production rate of less than 0.2 cell/day was observed (figure 2 ), so the

14 early start did not lead to a higher tree-ring cell number (figure 1). Although air and

15 humus temperature remain high until the end of August, cell production rate declines

16 after mid-July, corresponding to latewood cell production. Despite the differences

17 between years in the daily cell production rate, the total number of cells formed each

18 year was similar in 1998 and 1999, with asymptotes (i.e. total number of cells) of 36.6

19 and 37.6 cells respectively. The total was slightly higher in 2000, with 41.1 cells (figure

$201)$.

Figure 2

22 Cell production was influenced mainly by air and humus temperature during the week

23 when they were produced (table 1, lag 0). Lagging the weather variables by 1 to 5 days

24 did not improve the effects of weather variables. Positives correlations were found with

25 Tmin, weekly Tmax, Tmean and Thu, and were higher during the 7-day period between 
1 the sampling intervals (Lag 0). However, correlations with Thu remain almost

2 unchanged from a time lag of 1 to 5 days and are probably due to the lower daily

3 variation of humus temperature (figure 2). Only the correlation with weekly Tmin

4 improved with a time lag of 2 days, from $r=0.35$ at lag 0 to $r=0.40$, but still remained

5 lower than the one found with Tmin at lag $0(r=0.51)$. Positive correlations were found

6 with $\mathrm{P}$ and $\mathrm{RH}$ with a time lag of 4 days. No significant correlations were found with

$7 \quad \mathrm{Rad}$ and SW at lag 0 . These were not considered suitable for further regression analysis

8 because when the analysis was performed for each single year, the correlations changed

9 from positive to negative or were not considered to be significant (data not shown).

Table 1

11 Regression analyses with air and humus temperature were then performed with no time

12 lag as this represents the higher correlation found. The analyses showed that the rate of

13 cell production was positively influenced by air and humus temperature (table 2, figure

14 3). During the period when the majority of cells were produced, Tmin $\left(r^{2}=0.26\right)$ had a

15 greater impact on the rate of cell production than Tmean $\left(r^{2}=0.15\right)$ or $\operatorname{Tmax}\left(r^{2}=0.08\right)$.

16 Moreover, the coefficient of determination increased by $5-10 \%$ when performing the

17 analyses solely over the period of earlywood cell production. A higher increase was

18 observed for Tmin $\left(r^{2}=0.37\right)$. The results of the regression analyses showed that cell

19 production rate increases with Tmin distribution from 1 to $15^{\circ} \mathrm{C}$ (figure 3 ) representing

20 the average of the minimum temperatures of the week. The regression is lower $\left(r^{2}=0.19\right)$

21 if considering the minimum temperature occurring during the week (table 2, figure 3 ),

22 with the temperature distribution ranging from -4 to $13{ }^{\circ} \mathrm{C}$. As the growing season

23 started when minimum temperatures were above zero, the observations below zero were

24 related to frost events during the cell production period usually in May or June (figure

25 2). Since Thu shows high inter-correlation with Tmin (figure 2), its influence on cell 
1 production is only slightly lower than Tmin, with a coefficient of determination of

$2 \mathrm{r}^{2}=0.31$ for earlywood. In contrast to minimum air temperature, cells were not formed at

3 a humus temperature lower than $0{ }^{\circ} \mathrm{C}$ (figure 3 ). Thu is normally above $0{ }^{\circ} \mathrm{C}$ when cell

4 production begins. However, at the start of the growing season Thu varies from year to

5 year between 0 and $5{ }^{\circ} \mathrm{C}$ (figure 2). Cell production rate also increases positively with

6 Tmean and weekly Tmax, but the correlations were lower than those of Tmin, showing

7 less influence (table 2, figure 3).

8

Table 2

Figure 3 


\section{Discussion}

\section{Influence of weather factors on cell production}

3 Throughout the major period of cell division, air and humus temperature positively

4 influenced tracheid production. During earlywood formation, corresponding mainly

5 from the end of May to mid-July, the effect of temperature was slightly greater. Since

650 to $75 \%$ of tree-ring cells were formed during this period (from 1998 to 2000),

7 temperature variation strongly affects their rate of production. One of the primary

8 determinants of tree growth, temperature affects both leaf and meristem activity

9 (Kozlowski et al. 1991). Responses of cambial growth to temperature changes can be 10 rapid, as shown by a 1-day lag effect of temperature on daily radial growth of northern 11 oaks (Kozlowski and Pallady 1997). In our study, cell production was found to be 12 related with temperature within the same period that cells were produced. Lagging the 13 7-day period by just one day decreased the correlation with Tmin from 0.51 to 0.31 , 14 showing the high correspondence with the same interval when cell production was measured. These results also suggest a fast response of the cambium to temperature variation during tree-ring formation.

18 These results are not surprising, as temperature was found to define cell production and 19 differentiation at the earliest stage of cell differentiation of Larix sibirica Ldb. and Pinus silvestris L. (Wodzicki 1971; Antonova and Stasova 1993, 1997). In a northern

21 treeline area in Québec (Canada), by using the total tracheid production of Picea mariana (Mill.) BSP, Wang et al. (2002) found a positive correlation with a pentad 23 temperature of around $6-8{ }^{\circ} \mathrm{C}$ at the end of June. The results of this study are also 24 consistent with the higher response to temperature of a tree species growing near its northern distribution (Mäkinen et al. 2003), compared with other weather variables. In 
1 effect, significant and constant influences of the other weather variables on cell

2 production (i.e. global radiation, precipitation, humus water content and relative

3 humidity) were not found. The main factors affecting cell production remained constant

4 over the three years analysed suggesting one dominant factor, i.e. minimum

5 temperature. However, a longer period of detailed analysis would be required to confirm

6 this.

7

8 Although early summer precipitations had positive effects on annual growth of black

9 spruce (Brooks et al. 1998; Dang and Lieffers 1989; Hofgaard et al. 1999), white cedar

10 (Archambault and Bergeron 1992) and jack pine (Hofgaard et al. 1999), no relation was

11 found with precipitation at lag 0 . However, this is not in contrast with the result found

12 in dendroclimatology. For balsam fir, precipitation was associated with ring width

13 formation because of its effects on radial cell expansion (Deslauriers et al. 2003b) but

14 not with cell production. No biologically plausible reason was found to explain the

15 correlation with precipitation at lag 4.

17 The results of this study show that the lower threshold level allowing balsam fir tracheid

18 production during the cell division period is relatively low, being almost $0{ }^{\circ} \mathrm{C}$. In the

19 boreal forest other physiological processes, such as photosynthesis and nutrient uptake,

20 were also found to take place at low soil or air temperatures (close to $0{ }^{\circ} \mathrm{C}$ ) for species

21 including Picea mariana, Picea glauca and Pinus banksiana (Landhäuser et al. 1996;

22 Man and Lieffers 1997). Although humus temperatures were near $0{ }^{\circ} \mathrm{C}$ at the start of

23 cell production, a high rate of production was observed, as in May 1999. This was most

24 likely due to unusually high air temperatures for that period. Therefore, for some years,

25 soil temperature may not be the most suitable factor (or as good as air temperature) to 
1 explain the rate of cell production at the beginning of the growing season. Kirdyanov et

2 al. (2003) described the importance of snow melt timing for an increase in soil

3 temperature and growth initiation. Other studies in boreal zones, however, have reported

4 that the timing of bud burst and the beginning of root growth were unaffected by soil

5 temperatures (Domisch et al. 2001). From our 3-year study, the first cells showing

6 radial enlargement were observed at a humus temperature of between $0{ }^{\circ} \mathrm{C}$ and $5{ }^{\circ} \mathrm{C}$,

7 and from 0 to 2 weeks after snow melt, showing high variability and rendering

8 interpretations of cambial initiation difficult. Long-term tree-ring development analyses

9 are still required to explain the role of air and humus temperature and radiation on the

10 date of cambium initiation. Besides, other physiological process, such as the indole-3-

11 acetic-acid gradient across the cambial meristem and the influence of cambium activity

12 (Uggla et al. 1998) show complex interactions during the growing season, and not just

13 with meteorological factors.

15 General pattern of tree-ring cell production and temperature

16 The following questions arise from the obtained results; does a higher temperature

17 result in a greater amount of tracheids produced at the end of the growing season? and

18 how does temperature control the rate and duration of the cell production process? From

191998 to 2000 , the total number of cells was relatively similar despite differences in the

20 general sigmoid shape and duration period (Figure 1). At the intra-annual level it was

21 found that temperature variation influences the course of cell production, but at the end

22 of the formation period, the total number of cells can be offset by a reduction/increase in

23 the duration period. As a result, variations in the shape of the Gompertz sigmoid

24 function (i.e., inflection point position, slope at the inflection point, production rate) that

25 define the intra-annual general kinetic of tracheid production (Camarero et al. 1998; 
1 Deslauriers et al. 2003a; Rossi et al. 2003) seem to depend on the dynamics of seasonal

2 temperature variation but maybe not the asymptote (i.e., total number formed). Higher

3 temperatures must occur at the correct time during the growing season (June-July) to

4 significantly increase the total cell number. As total cell number does not depend solely

5 on the rate of cell division but also on the number of cells in the cambial zone (Vaganov

6 1990), only the long-term analysis of the total number of cells, as stated by Wang et al.

7 (2002), would allow such relationships to be found. Long-term detailed cell analyses are

8 therefore required to assess the effect of the long-term temperature pattern on total tree-

$9 \quad$ ring cell number production.

10

11 Acknowledgements. This work was funded by the Consortium de recherche sur la

12 forêt boréale commerciale, the Canada Foundation for Innovation, the Natural Sciences

13 and Engineering Research Council of Canada and Le Fonds Québécois de la Recherche

14 sur la Nature et les Technologies.

15 


\section{References}

2 Antonova GF, Stasova VV (1993) Effects of environmental factors on wood formation

3 in Scots pine stems. Trees 7: 214-219

4 Antonova GF, Stasova VV (1997) Effects of environmental factors on wood formation

5 in larch (Larix sibirica Ldb.) stems. Trees 11: 462-468

6 Archambault S, Bergeron Y (1992) An 802-year tree-ring chronology from the Quebec

7 boreal forest. Can J For Res 22: 674-682

8 Brooks JR, Flanagan LB, Ehleringer JR (1998) Responses of boreal conifers to climate

9 fluctuations : indications from tree-ring widths and carbon isotope analyses. Can J For

$10 \quad$ Res 28: 524-533

11 Camarero JJ, Guerrero-Campo J, Gutiérrez E (1998) Tree-ring growth and structure of

12 Pinus uncinata and Pinus sylvestris in the Central Spanish Pyrenees. Arct Alp Res 30:

$13 \quad 1-10$

14 Cheng, C, Gordon IL 2000. The Richards function and quantitative analysis of

15 germination and dormancy in meadowfoam (Limnanthes alba). Seed Sci Res 10: 265-

$16 \quad 277$

17 Creber GT, Chaloner WO (1990) Environmental influences on cambial activity. In The

18 vascular cambium, John Wiley \& Sons Ltd. Research Studies Press Ltd., pp 159-189

19 Dang QL, Lieffers VJ (1989) Climate and annual ring growth of black spruce in some

20 Alberta peatlands. Can J Bot 67: 1885-1889

21 D'Arrigo RD, Jacoby GC, Free RM (1992) Tree-ring width and maximum latewood 
1 density at the North American tree line: parameters of climatic change. Can J For Res

$222: 1290-1296$

3 Denne MP (1971) Temperature and tracheid development in Pinus sylvestris seedlings.

$4 \quad$ J Exp Bot 22: 362-370

5 Denne MP (1974) Effects of light intensity of tracheid dimensions in Picea sitchensis.

$6 \quad$ Ann Bot 38: 337-345

7 Deslauriers A (2003) Dynamique de la croissance radiale et influence météorologique

8 quotidienne chez le sapin baumier (Abies balsamea (L.) Mill.) en forêt boréale. Ph.D.

9 dissertation, Université du Québec à Chicoutimi, Chicoutimi, Canada

10 Deslauriers A, Morin H, Bégin Y (2003a) Cellular phenology of annual ring formation

11 of Abies balsamea in the Québec boreal forest (Canada). Can J For Res 33: 190-200

12 Deslauriers A, Morin H, Urbinati C, Carrer M (2003b) Daily weather response of

13 balsam fir (Abies balsamea (L.) Mill.) stem radius increment from dendrometer analysis

14 in the boreal forests of Québec (Canada). Trees 17: 477-484

15 Domisch T, Finér L, Lehto T (2001) Effect of soil temperature on biomass and

16 carbohydrate allocation in Scots pine (Pinus sylvestris) at the beginning of the growing

17 season. Tree Physiol 21: 465-472

18 Environnement Canada (1992) Sommaire métérologique mensuel, Chibougamau-

19 Chapais, janvier-décembre 1992. Service Environnement atmosphérique,

20 Environnement Canada, Ottawa, Ontario

21 Ford ED, Robards AW, Piney MD (1978) Influence of environmental factors on cell 
1 production and differentiation in the earlywood of Picea sitchensis. Ann Bot 42: 683-

2692

3 Hofgaard A, Tardif J, Bergeron Y (1999) Dendroclimatic response of Picea mariana

4 and Pinus banksiana along a latitudinal gradient in the eastern Canadian boreal forest.

$5 \quad$ Can J For Res 29: 1333-1346

6 Horacek P, Slezingerova J, Gandelova L Effects of environment on the xylogenesis of

7 Norway spruce (Picea abies [L.] Karst.) (1999) In R Wimmer, R Vetter (eds), Tree-ring

8 analysis: biological, methodological and environmental aspects. CABI Publ., pp.33-53

9 Kirdyanov AV, Hughes M, Vaganov EA, Schweingruber FH, Silkin P (2003) The

10 importance of early summer temperature and date of snow melt for tree growth in the

11 Siberian Subarctic. Trees 17: 61-69

12 Kozlowski TT, Kramer PJ, Pallardy SG (1991) The physiological ecology of woody

13 plants. Academic Press, San Diego, 657 pp

14 Kozlowski TT, Pallardy SG (1997) Growth control in woody plants. Academic Press,

15 New York, $641 \mathrm{pp}$

16 Landhäusser SM, Wein RW, Lange P (1996) Gas exchange and growth of three arctic

17 tree-line tree species under different soil temperature and drought preconditioning

18 regimes. Can J Bot 74: 686-693

19 Mäkinen H, Nöjd P, Kahle HP, Neumann U, Tveite B, Mielikäinen K, Röhle H,

20 Spiecker H (2003) Large-scale climatic variability and radial increment variation of

21 Picea abies (L.) Karst. in central and northern Europe. Trees 17: 173-184

22 Man R, Lieffers VJ (1997) Seasonal variations of photosynthetic capacities of white 
$1 \quad$ spruce (Picea glauca) and jack pine (Pinus banksiana) saplings. Can J Bot 75: 1766-

$2 \quad 1771$

3 Morin H (1994) Dynamics of balsam fir forest in relation to spruce budworm outbreaks

4 in the Boreal Zone of Quebec. Can J For Res 24: 730-741

5 Richardson SD, Dinwoodie JM (1960) Studies on the physiology of xylem

6 development. I. The effects of night temperature on tracheid size and wood density in

$7 \quad$ conifers. J Inst Wood Sci 6: 3-13

8 Rossi S, Deslauriers A, Morin H (2003) Application of the Gompertz equation for the

9 study of xylem cell development. Dendrochronologia 21: 1-7

10 SAS Institute Inc. (1990) SAS/STAT User's guide, version 6 ( $4^{\text {th }}$ edition), Vol. 2.

11 Uggla C, Mellerowicz EJ, Sundberg B (1998) Indole-3-acetic acid controls cambial

12 growth in Scots pine by positional signalling. Plant Physiol 117: 113-121

13 Vaganov EA (1990) The tracheidogram method in tree-ring analysis and its application.

14 In R Cook, L Kairiukstis (eds.), Methods of dendrochronology. Kluwer Academy,

15 Drodrecht, pp 63-76

16 Vaganov EA (1996) Analysis of seasonal tree-ring formation and modeling in

17 dendrochronology. In Dean JS, Meko DM, Swetnam TW (eds.), Tree-rings environment

18 and humanity. Proc Int Conf, Tucson, Arizona, 17-21 May. Radiocarbon: 73-87

19 Wang L, Payette S, Bégin Y (2002) Relationship between anatomical and densitometric

20 characteristics of black spruce and summer temperature at tree line in northern Québec

21 Can J For Res 32: 477-486 
1 Wodzicki TJ (1971) Mechanism of xylem differentiation in Pinus silvestris L. J Exp

2 Bot 22: 670-687

3 Zabuga VF, Zabuga GA (1990) Dynamics of morphometric indices of the annual ring

4 of Scotch pine in the forest-steppe of the Western Lake Baikal region. Lesovedenie 2:

$5 \quad 46-53$

6 Zar J H (1999) Biostatistical analysis. Upper Saddle River, New Jersey, 663 pp

7 
1 Table 1. Cross-correlation analysis between cell formation rate (sqrt [cell/day]) and

2 weather variables for a time-lag period from 0 to 5 days. The correlations were 3 considered significant (Pearson $p<0.05)$ over a correlation of $0.35(n=33)$. Lag 0

4 represents the weekly weather mean for the exact period between two sampling dates.

5 Time lag 1 to lag 5 represents the 7-day period shifted backwards from 1 to 5 days 6 before the sampling date. The highest coefficients of correlation are highlighted in grey.

7

\begin{tabular}{|l|c|c|c|c|c|c|}
\hline & Lag 0 & Lag 1 & Lag 2 & Lag 3 & Lag 4 & Lag 5 \\
\hline Tmin & 0.51 & 0.31 & 0.29 & 0.25 & 0.28 & 0.26 \\
\hline Week Tmin & 0.35 & 0.37 & 0.40 & 0.34 & 0.36 & 0.32 \\
\hline Tmax & 0.28 & 0.19 & 0.15 & 0.17 & 0.14 & 0.14 \\
\hline Week Tmax & 0.35 & 0.09 & 0.11 & 0.12 & 0.15 & 0.12 \\
\hline Thu & 0.50 & 0.42 & 0.44 & 0.45 & 0.46 & 0.47 \\
\hline Tmean & 0.38 & 0.24 & 0.21 & 0.21 & 0.21 & 0.21 \\
\hline Rad & -0.24 & -0.09 & -0.29 & -0.19 & -0.26 & -0.18 \\
\hline RH & 0.33 & 0.23 & 0.35 & 0.36 & 0.43 & 0.39 \\
\hline Sw & -0.06 & 0.01 & 0.01 & 0.02 & 0.03 & 0.03 \\
\hline P & -0.01 & 0.13 & 0.22 & 0.12 & 0.38 & 0.30 \\
\hline
\end{tabular}

9 Note: Tmean, mean temperature; Tmin, minimum temperature; Tmax, maximum

10 temperature; Week Tmin-Tmax, minimum-maximum temperature during the 7-day 11 period; Thu, humus temperature; Rad, global radiation; RH, relative humidity; SW, 12 humus water content; $\mathrm{P}$, precipitation. 
1 Table 2. Linear regression equation coefficient between cell production rate (sqrt

2 [cell/day]) and Tmean, Tmax, weekly Tmax, Tmin, weekly Tmin and Thu. Results are

3 shown for earlywood cell production only and the period when the majority of the cells

4 were produced.

\begin{tabular}{lcccccc}
\hline & Tmean & Thu & Tmin & $\begin{array}{c}\text { Weekly } \\
\text { Tmin }\end{array}$ & Tmax & $\begin{array}{c}\text { Weekly } \\
\text { Tmax }\end{array}$ \\
\hline \multicolumn{2}{l}{ Earlywood } & cell production $(\mathrm{n}=22)$ & & & & \\
$\mathbf{a}^{\mathbf{1}}$ & 0.3818 & 0.4544 & 0.4667 & 0.6941 & 0.4084 & 0.1726 \\
$\mathbf{b}$ & 0.0279 & 0.0369 & 0.0388 & 0.0222 & 0.0170 & 0.0222 \\
$\mathbf{R}^{2}$ & 0.20 & 0.31 & 0.37 & 0.19 & 0.11 & 0.17 \\
$\boldsymbol{p}$ & 0.03 & $<0.01$ & $<0.01$ & 0.04 & 0.12 & 0.04 \\
\hline $\mathbf{M}$ & 0.05 jar period of cell production $(\mathrm{n}=33)$ & & & \\
$\mathbf{a}$ & 0.4518 & 0.5083 & 0.5277 & 0.7151 & 0.4811 & 0.2847 \\
$\mathbf{b}$ & 0.0232 & 0.0285 & 0.0301 & 0.0159 & 0.0142 & 0.0187 \\
$\mathbf{R}^{2}$ & 0.15 & 0.25 & 0.26 & 0.12 & 0.08 & 0.13 \\
$\boldsymbol{p}$ & 0.03 & $<0.01$ & $<0.01$ & 0.04 & 0.12 & 0.04 \\
\hline
\end{tabular}

5

$6{ }^{1}$ Equation coefficients are based on the linear equation: sqrt (cell/day) $=a+b *[$ Tmean, Tmax, weekly

7 Tmax, Tmin, weekly Tmin or Thu]

8 
1

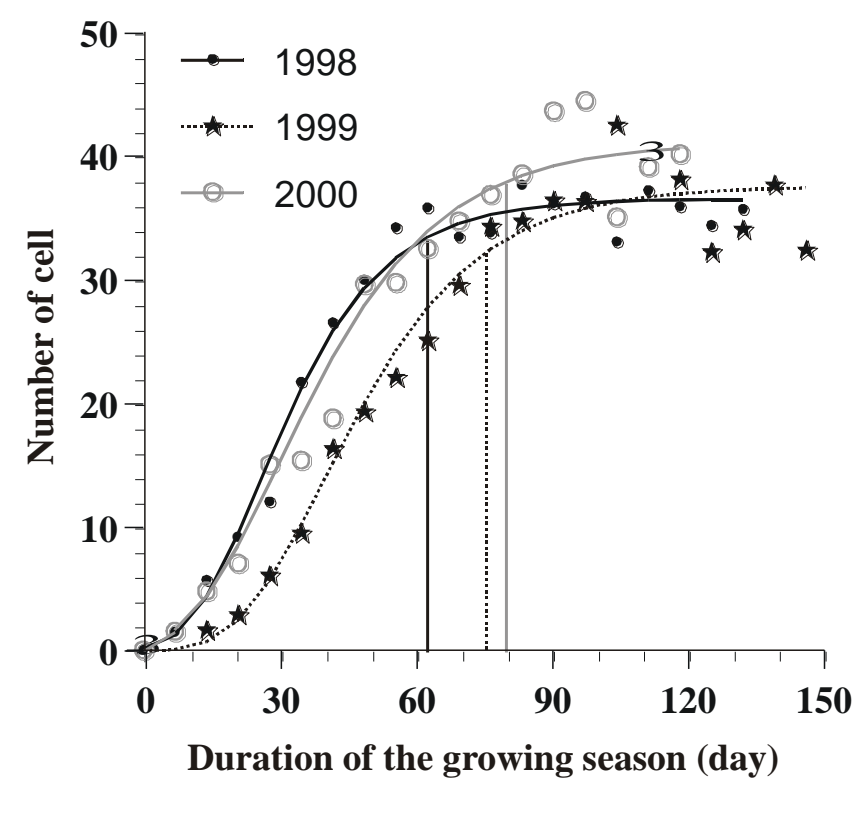

4 Figure 1. Cell number increase from the start of the growing season: mean total cell 5 number of ten trees counted each week and general logistic pattern of total cell

6 production from 1998 to 2000 . The vertical lines show the limit of the total period

7 analysed, representing the period when the majority of the cells were produced.

8 Parameters of the Gompertz equation from Deslauriers et al. (2003a): $1998 \mathrm{a}=36.6$,

$9 \beta=1.66$ and $\kappa=0.065,1999 \mathrm{a}=37.6, \beta=2.09$ and $\kappa=0.052,2000 \mathrm{a}=41.1, \beta=1.51$ and $10 \kappa=0.05$. 

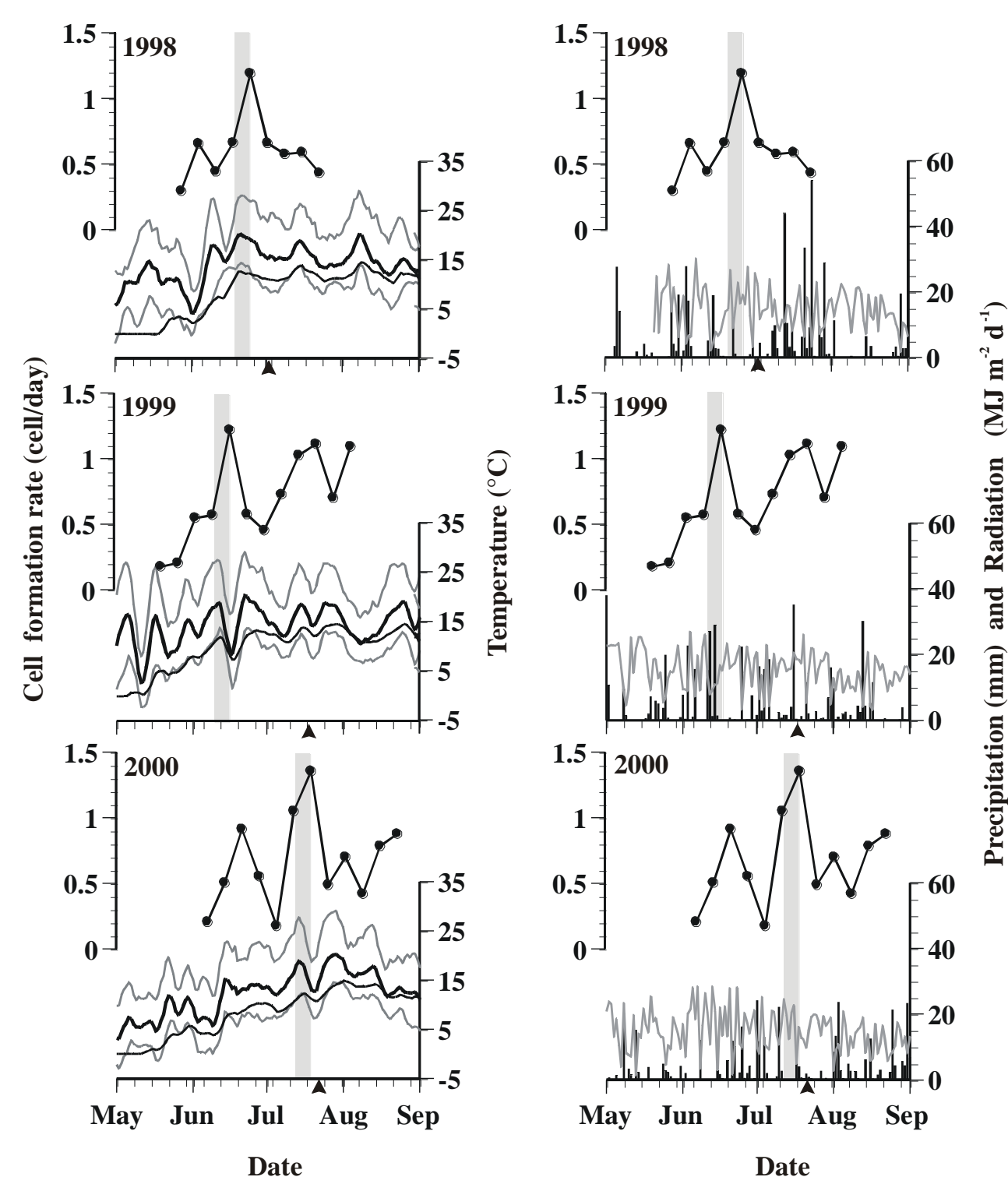

Figure 2. Cell formation rate (cell/day), temperatures, precipitation and radiation

5 variations from May to September for 1998 to 2000. Lower left, mean (thick black line)

6 maximum, minimum (grey line) and humus temperature (thin black line). Lower right,

7 precipitation (black vertical lines) and radiation (grey line). Air temperature variations

8 were smoothed for better graphic representation. The vertical grey bands highlight the 7

9 days weather conditions before the higher cell formation rate observed each year. The

10 triangles indicate the earlywood to latewood transition as found in Deslauriers et al.

11 2003. The horizontal axis major tick marks show one month and minor tick marks one

12 week intervals. 


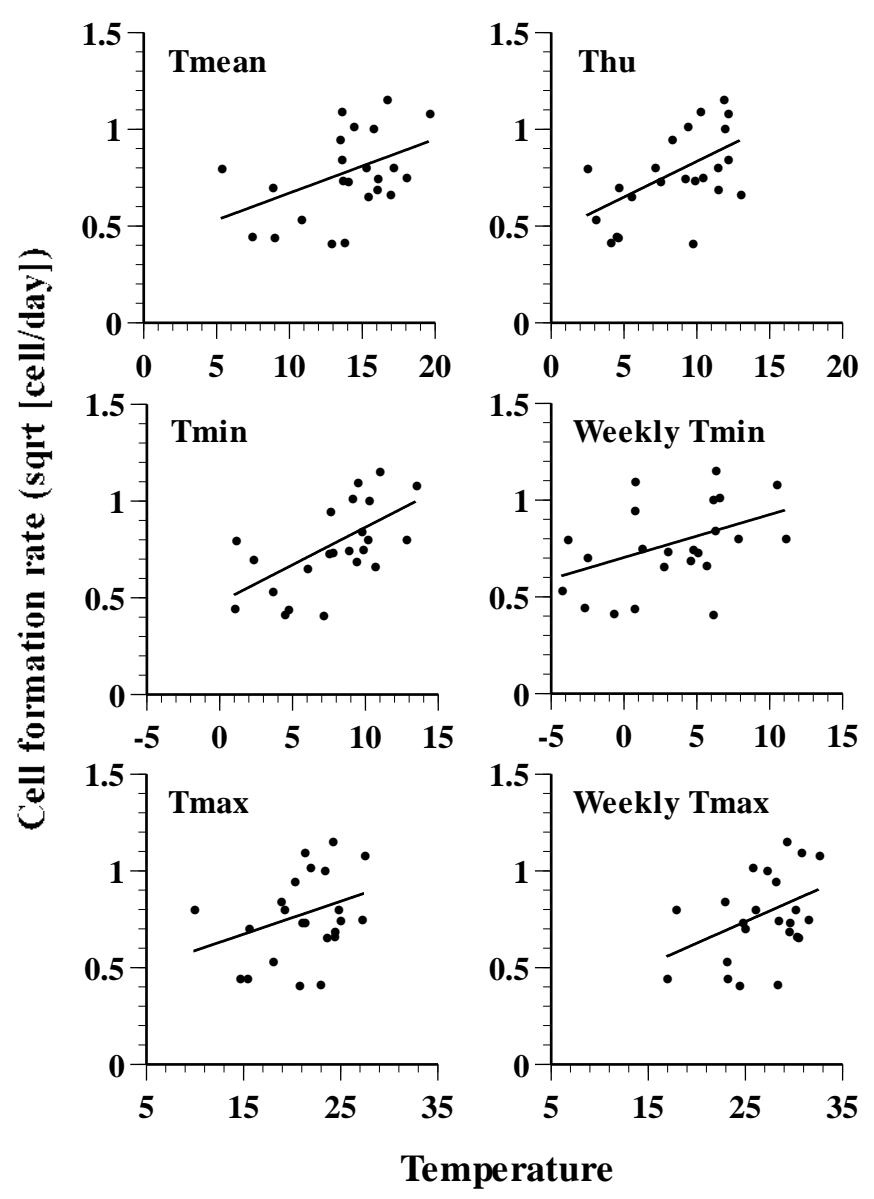

2

3 Figure 3. Relationship between square root cell formation rate (sqrt [cell/day]) and

4 Tmean, Thu, Tmax, weekly Tmax, Tmin and weekly Tmin during earlywood cell 5 production. 